249 Nurkholis

Metode Pembelajaran Bahasa Arab

\title{
METODE PEMBELAJARAN BAHASA ARAB DI PONDOK PESANTREN TRADISIONAL
}

\author{
Nurkholis \\ Institut Agama Islam Negeri (IAIN) Metro \\ Email:kholisn43@yahoo.com
}

\begin{abstract}
Arabic language is must to learn in pesantren, because Arabic language used in a classic books in Arabic, the actifity of worship is done daily also with the Arabic language. Pesantren is the only educational institution studying Arabic in the old of the development of Islam, even today. Arabic learning methods used by pesantren, especially traditional pesantren have been decades old using qawaid wa tarjamah method. The method does this even become a grip or characteristic of the learning process undertaken in traditional pesantren, since the majority assume that the existing learning method is the best method in the learning process, thus overriding new methods or the existence of other methods which is likely to be more effectively used in the learning of the A rabic language. There needs to be a review of the learning methods currently used by boarding schools, so that learning Arabic language can facilitate the learner or santri.
\end{abstract}

Keywords: Method, Learning Arabic, Traditional Pesantren.

\begin{abstract}
Abstrak
Pembelajaran Bahasa Arab di pesantren adalah suatu keharusan, karena bahasa yang dipakai dalam kitab-kitab terdahulu berbahasa Arab, ritual ibadah yang dilakukan sehari-hari juga dengan bahasa Arab. Pesantren adalah satu-satunya lembaga pendidikan yang mempelajari bahasa Arab pada era awal perkembangan agama Islam, bahkan hingga saat ini. Metode pembelajaran bahasa Arab yang digunakan oleh pesantren, khususnya pesantren tradisional sudah berpuluh-puluh tahun menggunakan metode qawaid wa tarjamah. Sistem pembelajaran yang turun temurun dilakukan ini bahkan menjadi suatu pakem atau ciri khas proses pembelajaran yang dilakukan di pesantren tradisional, karena mayoritas menganggap bahwa metode pembelajaran yang sudah ada itu adalah metode yang terbaik dalam proses pembelajaran, sehingga mengesampingkan metode-metode baru atau adanya metode lain yang mempunyai kemungkinan lebih efektif digunakan dalam pembelajaran bahasa Arab tersebut. Perlu adanya penelaahan kembali tentang metode pembelajaran yang saat ini digunakan oleh pondok pesantren, agar pembelajaran bahasa Arab dapat mempermudah para pembelajar atau santri.
\end{abstract}


Kata Kunci : Metode, Pembelajaran Bahasa Arab, Pesantren Tradisional.

\section{A. Pendahuluan}

Pembelajaran bahasa Arab di Indonesia sudah dilakukan sejak lama, bahkan dimulai sejak agama Islam dikenalkan di Indonesia oleh orang Saudi Arabia sekitar abad ke-13, walaupun belum ada penelitian yang mengungkap dengan pasti perihal awal mula pembelajaran bahasa Arab, namun sudah bisa dipastikan ketika agama Islam mulai dikenalkan di Indonesia, maka bahasa Arab juga sudah mulai dipelajari, karena memang agama Islam tidak dapat terlepas dari bahasa Arab. Hal ini dikarenakan kitab suci umat Islam berbahasa Arab, buku-buku tentang pembelajaran pendidikan Agama Islam banyak yang berbahasa Arab, begitu juga dalam setiap ritual ibadah yang dilakukan oleh umat Islam adalah dengan menggunakan bahasa Arab.

Pada era awal perkembangan Islam di Indonesia, dalam catatan sejarah, Pondok Pesantren dikenal di Indonesia sejak zaman Walisongo. Ketika itu Sunan Ampel mendirikan sebuah padepokan di Ampel Surabaya dan menjadikannya pusat pendidikan di pulau Jawa. Para santri yang berasal dari pulau Jawa datang untuk menuntut ilmu agama. Bahkan diantara para santri ada yang berasal dari Gowa dan Talo, Sulawesi. ${ }^{1}$ Pesantren didirikan oleh wali songo pada saat itu digunakan sebagai tempat untuk menimba ilmu-ilmu agama Islam, termasuk di dalamnya mempelajari bahasa Arab. Pesantren berkembang sangat pesat ke berbagai daerah, karena santri yang belajar di pesantren diberikan beban tugas untuk mengamalkan dan menyebarkan ilmu yang diperolehnya di daerah masing-masing, sehingga setiap santri yang kembali ke daerahnya kemudian mendirikan pesantren yang santrinya berasal dari berbagai daerah, dan setelah selesai juga kembali ke daerahnya dan mendirikan pesantren lagi, begitu seterusnya sehingga pesantren tumbuh dengan sangat pesat di tanah Jawa bahkan hingga saat ini sudah meluas di luar pulau Jawa. Pesantren di Indonesia memiliki peran yang sangat besar, baik bagi kemajuan Islam itu sendiri maupun bagi Indonesia secara keseluruhan.

${ }^{1}$ Muhammad Jamhuri, Sejarah dan Perkembangan Pendidikan Islam di Indonesia,(Tangerang: Sekolah Tinggi Agama Islam Asy-Syukriyyah,1990), h. 1. 
Pesantren yang ada di Indonesia menjadi satu-satunya tempat yang mempelajari bahasa Arab pada saat itu. Kitab-kitab agama Islam pada saat itu semua berbahasa Arab, sehingga untuk mempelajari maupun memperdalam tentang agama Islam maka harus bisa menguasai bahasa Arab terlebih dahulu. Pembelajaran bahasa Arab yang ada di pesantren tidak terlepas dari peran seorang kiyai sebagai tenaga pendidik sekaligus sebagai pemimpin di pesantren tersebut, sehingga segala sesuatu yang berkaitan dengan proses pembelajaran, baik pendekatannya, metodenya, tekniknya, maupun strateginya adalah di bawah komando kiai atau berdasarkan pada kebijakannya. Pembelajaran yang ada di pesantren mempunyai kesamaan, yaitu rasa hormat dan taatnya terhadap kiai, sehingga apapun yang dilakukan seorang kiai akan menjadi referensi atau teladan para santrinya, begitu juga dalam hal pembelajarannya menjadi acuan para santri yang kemudian diterapkan di pesantren yang didirikannya.

Sistem pembelajaran yang akhirnya turun temurun dilakukan ini bahkan menjadi suatu pakem atau ciri khas proses pembelajaran yang dilakukan di pesantren tradisional, karena mayoritas menganggap bahwa metode pembelajaran yang sudah ada itu adalah metode yang terbaik dalam proses pembelajaran, sehingga mengesampingkan metode-metode baru atau adanya metode lain yang mempunyai kemungkinan efektif digunakan dalam pembelajaran, bahkan tidak sedikit yang kemudian mengkeramatkan tentang metode pembelajaran tersebut.

\section{B. Metode Pembelajaran Bahasa Arab}

Metode berasal dari kata methodos dari bahasa latin, sedangkan methodos itu sendiri berasal dari akar kata meta dan hodos. Meta berarti menuju, melalui, mengikuti, sesudah, sedangkan hodos berarti jalan, cara, arah. Dalam pengertian yang lebih luas, metode dianggap sebagai cara-cara, strategi untuk memahami realitas, langkah-langkah sistematis untuk memecahkan rangkaian sebab akibat berikutnya. Sebagai alat, metode berfungsi untuk menyederhanakan masalah sehingga lebih mudah dipecahkan dan dipahami. Metode merupakan instrumen dan dipergunakan untuk mencapai tujuan pendidikan atau alat yang mempunyai fungsi ganda, yaitu yang bersifat polipragmatis dan monopragmatis. Oleh karena itu, secara umum metode diartikan 
sebagai cara mengerjakan sesuatu, cara itu mungkin baik mungkin tidak baik. Metode juga dapat diartikan sebagai cara untuk mempermudah pemberian pemahaman kepada anak didik mengenai bahan atau materi yang diajarkan.

Metode secara umum adalah segala hal yang termuat dalam setiap proses pengajaran, seperti usaha, aturan serta sarana dan gaya penyajian. ${ }^{2}$ Metode juga diartikan sebagai sistematika umum bagi pemilihan, penyusunan serta penyajian materi kebahasaan. Pemilihan, penentuan, dan penyusunan bahan ajar secara sistematis dimaksudkan agar bahan ajar tersebut mudah diserap dan dikuasai oleh siswa. Semuanya itu didasarkan pada pendekatan yang dianut. Melihat hal itu, jelas bahwa suatu metode ditentukan berdasarkan pendekatan yang dianut; dengan kata lain, pendekatan merupakan dasar penentu metode yang digunakan. Dalam hal ini, setelah guru menetapkan tujuan yang hendak dicapai kemudian ia mulai memilih bahan ajar yang sesuai dengan bahan ajar tersebut yang sekiranya sesuai dengan tingkat usia, tingkat kemampuan, kebutuhan serta latar belakang lingkungan siswa. Kemudian, bahan ajar tersebut disusun menurut urutan tingkat kesukaran, yakni dari yang mudah berlanjut pada yang lebih sukar. Di samping itu, guru merencanakan pula cara mengevaluasi, mengadakan remidi serta mengembangkan bahan ajar tersebut.

Metode pengajaran bahasa asing sangat banyak dan beraneka ragam, telah terjadi perdebatan yang cukup panjang dikalangan para pakar dibidang ini. Sebagian mereka mengunggulkan suatu metode dengan mengungkapkan kelebihan-kelebihannya, dan pada saat yang sama mereka mengungkap kelemahan-kelemahan metode lainnya, dan memang semua metode mempunyai kelemahan dan kelebihan masing-masing.

Sedangkan menurut Ahmad Izzan, yang dimaksud dengan metode pembelajaran Bahasa Arab adalah cara atau jalan yang ditempuh bagaimana menyajikan bahan-bahan pelajaran dan bahasa Arab, agar mudah diterima, diserap dan dikuasai oleh anak didik dengan baik dan menyenangkan. ${ }^{3}$

2 Abdul Hamid, Uril Baharuddin, Bisri Mustofa, Pembelajaran Bahasa Arab ( Malang : UIN Malang Press, 2008), h. 3.

${ }^{3}$ Ahmad Izzan, Metodologi Pembelajaran Bahasa Arab, (Bandung : Humaniora, 2009), h. 72. 
Secara umum, ada yang membagi metode pembelajaran menjadi dua macam, yaitu metode konvensional/klasik dan metode inkonvensional/modern. Metode inkonvensional atau modern adalah suatu teknik mengajar yang baru berkembang dan belum lazim digunakan secara umum. Metode ini masih merupakan metode yang baru dikembangkan dan diterapkan di beberapa sekolah tertentu, yang mempunyai peralatan dan media yang lengkap serta guru-guru yang ahli menanganinya. Arsyad mengungkapkan bahwa metode pengajaran bahasa asing untuk pengajaran bahasa Arab merupakan ilmu yang baru berkembang kemudian, jauh di belakang perkembangan metode pengajaran bahasa Inggris. Meskipun demikian, bukan berarti metode pengajaran bahasa Arab selama ini yang masih bersifat 'tradisional' itu tidak berhasil, bahkan dianggap cukup banyak membawa keberhasilan. Beberapa metode pembelajaran bahasa Arab, yang bersifat konvensional diantaranya adalah: Metode Grammar dan Terjemah/Grammar and Translation Method. Metode Grammar dan Terjemah merupakan metode paling tua dari semua metode pembelajaran bahasa Arab. Metode ini dikenal di Amerika Serikat pada akhir abad ke-19, dengan nama bermacam-macam di antaranya dengan nama metode Prusia. Pada tahun 1930-an terkenal dengan metode Grammar dan Terjemah karena hanya memfokuskan pada kajian grammar atau tata bahasa dengan pola pengajaran teori bahasa secara langsung yaitu menerjemahkan kaidah-kaidah tata bahasa, kalimat kalimat, dan susunan kalimat dari bahasa sumber/asing ke bahasa asal/ibu. ${ }^{4}$

Sedangkan menurut Yayan Nurbayan metode pengajaran bahasa asing terbagi menjadi empat metode dasar yaitu, metode Qawa"idTarjamah, metode langsung, metode Sam "iyyah- Syafawiyyah (dengarucap), dan metode eklektik. ${ }^{5}$

1. Metode Qawa"id-Tarjamah

Metode ini mempunyai beberapa nama. Sebagian orang menyebutnya metode klasik. Dan sebagian lain menyebutnya metode

${ }^{4}$ Abdul Aziz ibn Ibrahim al-'Ushaili, Tharâiq Tadrîs al-Lughah al-'Arabiyah lin Nâtiqîn bi Lughatin Ukhrâ (Riyadh: Jami'ah Imam Muhammad ibn Su'ud al-Islamiyah, $2002 \mathrm{M} / 1423 \mathrm{H})$, hal. 33-34.

5 Yayan Nurbayan, Metodologi Pembelajaran Bahasa Arab, (Bandung : Zein Al Bayan, 2008), h. 18-20 
Taqlidiyyah. Gambaran-gambaran penting mengenai metode ini adalah sbb:

a. Metode ini sangat memperhatikan keterampilan membaca, menulis, dan terjemah. Sedangkan kemampuan berbicara kurang diperhatikan.

b. Metode ini menggunakan bahasa ibu sebagai media utama dalam pengajaran bahasa yang dimaksud. Dengan perkataan lain bahwa metode ini menggunakan terjemah sebagai cara utama dalam pengajarannya.

c. Metode ini sangat memperhatikan aturan-aturan ilmu Nahwu sebagai media untuk mengajarkan bahasa asing. Sehingga ketepatan bacaan sangat diperhatikan.

d. Kebanyakan guru yang menggunakan metode ini terjebak pada analisis sintaksis untuk setiap kalimat bahasa asing yang diajarkannya.

e. Dan biasanya para guru juga meminta para pembelajar untuk mengikuti hal tersebut.

2. Metode Langsung

Karena banyaknya kritikan terhadap metode Qawa'idTarjamah muncullah metode baru yang dinamakan dengan metode langsung. Metode ini mempunyai beberapa kelebihan sbb:

a. Metode ini memberikan banyak waktu untuk melatih keterampilan berbicara sebagai ganti dari keterampilan membaca, menulis, dan menterjemahkan. Hal ini didasarkan atas prinsip bahwa esensi utama bahasa adalah berbicara.

b. Metode ini sangat menghindari penerjemahan saat pengajaran bahasa asing yang diajarkan sedang berlangsung. Penerjemahan, menurut para pendukungnya sangat sedikit manfaatnya, bahkan sangat mengganggu dalam pengajaran bahasa asing.

c. Aspek positif dari metode ini, tidak ada tempat bagi bahasa ibu dalam pengajaran bahasa asing.

d. Dalam prakteknya, metode ini selalu mengaitkan antara kata-kata yang diajarkan dengan objek-objek yang ditunjuk oleh kata-kata tersebut, antara suatu kalimat dengan situasi yang diungkapkannya. Dengan demikian metode ini dinamakan metode langsung.

e. Metode ini tidak menggunakan analisis nahwu. Para pendukung metode ini berpendapat bahwa aturan-aturan tersebut tidak 
berguna dalam mencapai keterampilan berbahasa yang diharapkan.

f. Metode ini menggunakan model meniru dan menghapal. Para pembelajar diberi kalimat-kalimat bahasa asing, nyanyiannyanyian, dan dialog-dialog yang dapat membantu mereka memantapkan bahasa asing yang dipelajarinya.

3. Metode Ucap-dengar (oral-oral approach)

Metode Ucap-dengar merupakan alternatif dari kedua metode terdahulu, yaitu metode Qawaid-Tarjamah dan metode Langsung. Metode ini mempunyai beberapa nama, seperti metode Syafawiyyah (metode ucap) dan metode Lughawiyyah (metode Kebahasaan). Pada awalnya metode ini dinamakan dengan metode Tentara. Istilah ini digunakan, karena metode ini untuk pertama kalinya digunakan dalam mengajarkan bahasa kepada para tentara Amerika yang akan berperang setelah usai perang dunia kedua. Asumsi-asumsi yang digunakan oleh metode ini antara lain :

a. Essensi bahasa adalah berbicara. Sedangkan menulis merupakan bagian dari gambaran berbicara. Oleh karena itu perhatian dalam pengajaran bahasa asing hendaklah dicurahkan untuk tercapainya keterampilan berbicara, bukannya keterampilan membaca atau menulis.

b. Proses pengajaran bahasa hendaklah mengikuti urutanurutan tertentu, yaitu : mendengar, berbicara, membaca, dan menulis. Ini berarti bahwa para pembelajar untuk pertama kali hendaklah dilatih mendengar, kemudian mereka mengucapkan apa yang didengarnya. Setelah itu mereka belajar membaca, dan diikuti dengan menulis apa yang dibacanya.

c. Proses pencapaian kemampuan berbahasa asing sama dengan proses pencapaian kemampuan seorang anak pada bahasa ibunya. Pertama kali mereka mendengar, kemudian meniru apa yang mereka dengar. Setelah itu mereka belajar di sekolah untuk belajar membaca dan menulis.

d. Sebaik-baiknya metode pemerolehan bahasa asing adalah dengan pembentukan kebiasaan kebiasaan dalam bahasa, yaitu dengan jalan berlatih melalui pola-pola. 
e. Para pembelajar sangat membutuhkan belajar bahasa asing, bukannya tentang bahasa asing. Ini berarti bahwa mereka perlu latihan pengucapannya. Sangat kurang manfaatnya bagi mereka mengetahui aturan-aturannya serta analisis kebahasaannya.

f. Setiap bahasa mempunyai sistemnya tersendiri. Tidaklah bermanfaat studi tentang kontrastif dan perbandingan.

g. Terjemah bisa mengacaukan dalam pengajaran bahasa asing, sehingga tidak perlu digunakan.

h. Sebaik-baik guru bahasa asing adalah penutur asli. Sebagaimana setiap metode pada umumnya.

\section{Metode Eklektik}

Metode ini muncul sebagai respon atas munculnya ketiga metode di atas. Asumsi-asumsi metode ini adalah sbb :

a. Setiap metode mempunyai kelebihan-kelebihan tersendiri, dan kelebihan-kelebihan tersebut mungkin bisa dimanfaatkan untuk pengajaran bahasa asing.

b. Tak ada satu metode pun yang sempurna, sebagaimana halnya tidak ada satu metode pun yang salah total. Tiap tiap metode mempunyai kelebihan dan kekurangannya masing-masing.

c. Pandangan bahwa suatu metode dapat melengkapi metode lainnya lebih baik dari pada pandangan bahwa antara metodemetode terdahulu terdapat saling pertentangan.

d. Tak ada satu metode pun yang relevan untuk semua tujuan, semua pembelajar, semua guru, dan semua program pengajaran.

e. Prinsip utama dalam pengajaran terpusat pada pembelajar dan kebutuhannya. Bukannya kepada metode tertentu tanpa memperhitungkan kebutuhan pembelajar.

f. Seorang guru hendaklah merasa bebas dalam memilih metode yang akan digunakannya sesuai dengan kondisi siswa, dan dengan tidak menutup mata dari berbagai penemuan baru dalam metodologi pengajaran. Seorang guru mungkin dapat memilih satu metode atau beberapa metode yang sesuai dengan kebutuhan siswa dan situasi belajar-mengajar.

\section{Pondok Pesantren Tradisional}

Istilah pesantren berasal dari kata pe-santri-an, dimana kata "santri" berarti murid dalam Bahasa Jawa, istilah pondok berasal 
dari Bahasa Arab funduuq (فندوق) yang berarti penginapan. Khusus di daerah Aceh, pesantren disebut juga dengan nama dayah. Biasanya pesantren dipimpin oleh seorang Kyai, Untuk mengatur kehidupan pondok pesantren, kyai menunjuk seorang santri senior untuk mengatur adik-adik kelasnya, mereka biasanya disebut lurah pondok. Tujuan para santri dipisahkan dari orang tua dan keluarga mereka adalah agar mereka belajar hidup mandiri dan sekaligus dapat meningkatkan hubungan dengan kyai dan juga Alloh.

Pendapat lainnya, pesantren berasal dari kata santri yang dapat diartikan tempat santri. Kata santri berasal dari kata Cantrik (bahasa Sansakerta, atau mungkin Jawa) yang berarti orang yang selalu mengikuti guru, yang kemudian dikembangkan oleh Perguruan Taman Siswa dalam sistem asrama yang disebut Pawiyatan. Istilah santri juga dalam ada dalam bahasa Tamil, yang berarti guru mengaji, sedang C.C Berg berpendapat bahwa istilah tersebut berasal dari istilah shastri, yang dalam bahasa India berarti orang yang tahu buku-buku suci agama Hindu atau seorang sarjana ahli kitab suci agama Hindu. Terkadang juga dianggap sebagai gabungan kata saint (manusia baik) dengan suku kata tra (suka menolong), sehingga kata pesantren dapat berarti tempat pendidikan manusia baik-baik. ${ }^{6}$

Pendapat yang lain mengatakan bahwa pesantren menurut pengertian dasarnya adalah tempat belajar para santri. Sebagai lembaga pendidikan Islam, pesantren dari sudut historis kultural dapat dikatakan sebagai "training centre" yang otomatis menjadi pusat budaya Islam, yang disahkan atau dilembagakan oleh masyarakat, setidaknya oleh masyarakat Islam sendiri yang secara de facto tidak dapat diabaikan oleh pemerintah. Itulah sebabnya Nurcholish Madjid mengatakan bahwa dari segi historis, pesantren tidak hanya identik dengan makna ke-Islaman, tetapi juga mengandung makna keaslian Indonesia (indigenous). ${ }^{7}$

Pesantren, secara sederhana mulanya dimengerti sebagai tempat mangkalnya sekelompok orang saleh yang ingin mendalami agama Islam, dengan seorang kyai tertentu sebagai tokoh spiritual mereka.

${ }^{6}$ Fatah, H Rohadi Abdul, Taufik, M Tata, Bisri, Abdul Mukti. Rekontruksi Pesantren Masa Depan, (Jakarta Utara: PT. Listafariska Putra, 2005), hal.11.

7 Nurcholish Madjid, Bilik-Bilik Pesantren Sebuah Potret Perjalanan (Jakarta: Paramadina, 1997), h. 59. 
Kata "santri" sendiri sebenarnya punya dua pengertian. Pertama, bisa berarti orang mendalami agama Islam. Kedua, bisa berarti juga orang saleh yang beribadat dengan sungguh-sungguh. Pada perkembangan selanjutnya, setiap orang yang bermukim di pesantren, walaupun karena dipaksa oleh orang tua karena biaya pendidikan yang mahal, atau karena frustasi dan karenanya ia tetap bandel di pesantren tanpa menunjukkan sedikitpun tanda-tanda orang saleh tetap disebut santri, itu soal lain.

Sebuah pesantren pada dasarnya adalah sebuah asrama pendidikan Islam tradisional di mana para siswanya tinggal bersama dan belajar di bawah bimbingan seorang (atau lebih) guru yang lebih dikenal dengan sebutan kyai. Berdasarkan jumlah siswa atau santrinya, pesantren dapat dikelompokkan menjadi tiga macam, antara lain: pesantren kecil, yaitu pesantren yang biasanya mempunyai jumlah santri di bawah seribu dan pengaruhnya terbatas pada tingkat kabupaten, pesantren menengah, yaitu pesantren yang memiliki jumlah santri antara 1000 sampai dengan 2000 orang, pesantren menengah ini biasanya memiliki pengaruh dan menarik santri-santri dari beberapa kabupaten, dan pesantren besar, yaitu pesantren yang mempunyai jumlah santri lebih dari 2000 orang yang berasal dari berbagai kabupaten dan propinsi. Selain itu, dikenal pula istilah-istilah pesantren, seperti: Pesantren Tradisional, Pesantren Modern dan Pesantren Kilat. Pesantren tradisional atau pesantren salafiyah adalah pesantren yang tetap mempertahankan pengajaran kitab-kitab Islam klasik sebagai inti pendidikan di pesantren. Sistem madrasah atau jenjang-jenjang juga diterapkan untuk lebih memudahkan sistem pengajaran yang dipakai dalam lembaga-lembaga pengajian bentuk lama, pesantren ini tidak mengenalkan pengajaran pengetahuan umum. Misalnya, Pesantren Lirboyo dan Ploso di Kediri, Pesantren Aslakul Huda di Pati dan pesantren Tremas di Pacitan. Pesantren modern atau pesantren khalafi adalah pesantren yang telah memasukkan pelajaran-pelajaran umum dalam sistem madrasahmadrasah yang dikembangkannya, atau membuka tipe sekolah umum dalam lingkungan pesantren. Misalnya, Pondok Modern Gontor di Ponorogo yang tidak lagi mengajarkan kitab-kitab Islam klasik atau Pesantren Tebuireng dan Rejoso di Jombang yang telah membuka SMP, 
SMA dan universitas namun tetap mempertahankan pengajaran kitabkitab Islam klasik. ${ }^{8}$

Pesantren tradisional/salaf memang termasuk lembaga pendidikan yang memiliki karakteristik yang unik diantaranya adalah dalam sistem pembelajarannya yang masih tetap mempertahankan sistem pendidikan tradisional, walaupun keberadaan tipologi pesantren pada saat ini telah mengalami perubahan, sehingga ada yang dinamakan pondok pesantren salaf dan pesantren khalaf. ${ }^{9}$

Berdasarkan uraian tersebut di atas dapat diambil suatu kesimpulan bahwa pesantren adalah suatu tempat seseorang yang tinggal di rumah-rumah atau pemondokan dengan tujuan untuk mendalami ilmu-ilmu agama dengan bimbingan orang yang banyak mempunyai pengetahuan agama yang kemudian disebut dengan kiai atau ustad. Adapun saat ini makna pesantren sudah mengalami banyak kemajuan, karena di pesantren tersebut sekarang bukan hanya mempelajari materi-materi keagamaan saja, tapi sudah meluas pada pengetahuan atau keterampilan yang lain, begitu juga dalam pengelolaannya, pesantren saat ini sudah dikelola dengan berbagai strategi dan juga metode dengan dalih mengikuti perkembangan zaman dan pengetahuan. Kendatipun demikian, masih banyak pesantren yang tetap mempertahankan metode pembelajarannya seperti yang dilakukan oleh pesantren-pesantren yang terdahulu, mayoritas mereka menganggap metode yang ada sejak dahulu adalah metode yang terbaik, karena telah terbukti dari outputnya, yaitu telah melahirkan ulama-ulama dan tokoh-tokoh yang kemudian juga mendirikan pesantren lagi.

\section{Pembelajaran Bahasa Arab di Pesantren Tradisional}

Seiring perkembangan zaman, serta tuntutan masyarakat atas kebutuhan pendidikan umum, kini banyak pesantren yang menyediakan menu pendidikan umum dalam pesantren, kemudian muncul istilah pesantren tradisional atau salaf dan pesantren modern,

\footnotetext{
${ }^{8} \mathrm{http} / / / \mathrm{www}$. inidalwa.ac.id/pembelajaran-bahasa-arab-di-pesantren-tradisionalkurikulum-tujuan-bahan-ajar-dan-metode/ diunduh pada 30 Oktober 2017.

9 Hamid Fahmi Zarkasyi, Pengembangan Institusional dan Kurikuler Pesantren Salafiyah, Makalah "Seminar Pengembangan Pesantren Salafiyah" yang diselenggrakan Puslitbang Pendidikan Agama dan Keagamaan, tanggal 8-10 Juni 2007.
} 
pesantren tradisional atau salaf hanya mengajarkan pendidikan agama sedangkan pesantren yang modern menggunakan system pengajaran pendidikan umum atau kurikulum.

Menurut Zamakhsyari Dhofier ada beberapa ciri pesantren salaf atau tradisional, terutama

a. Dalam hal sistem pengajaran dan materi yang diajarkan. Pengajaran kitab-kitab Islam klasik atau sering disebut dengan "kitab kuning", karena kertasnya berwarna kuning, terutama karangan-karangan ulama yang menganut faham Syafi'iyah. Semua ini merupakan pengajaran formal yang diberikan dalam lingkungan pesantren tradisional. Abdurrahman Wahid mencatat bahwa ciri utama dari pengajian pesantren tradisional ini adalah cara pemberian pengajarannya yang ditekankan pada penangkapan harfiah (litterlijk) atas suatu kitab (teks) tertentu.

b. Pendekatan yang digunakan adalah menyelesaikan pembacaan kitab (teks) tersebut, untuk kemudian dilanjutkan dengan pembacaan kitab (teks) lain.

c. Sistem individual dalam sistem pendidikan Islam tradisional disebut system sorogan yang diberikan dalam pengajian kepada muridmurid yang telah menguasai pembacaan Al-Quran.

d. Metode utama sistem pengajaran di lingkungan pesantren tradisional adalah sistem bandongan atau seringkali juga disebut sistem weton. Dalam sistem ini sekelompok murid (antara 5 sampai 500 orang) mendengarkan seorang guru membaca, menerjemahkan, menerangkan, dan seringkali mengulas buku-buku Islam dalam bahasa Arab. Setiap murid memerhatikan bukunya atau kitabnya sendiri dan membuat catatan-catatan (baik arti maupun keterangan) tentang kata-kata atau buah pikiran yang sulit. Kelompok kelas dari sistem bandongan ini disebut halaqah yang arti bahasanya lingkaran murid, atau sekelompok siswa yang belajar di bawah bimbingan seorang guru.

Ciri lain yang didapati di pesantren salaf adalah mulai dari budaya penghormatan dan rasa ta'zhim pada guru dan kiai, kegigihan belajar yang disertai sejumlah ritual tirakat: puasa, wirid, dan lainnya, hingga kepercayaan pada barakah. ${ }^{10}$

\section{${ }^{10}$ Ibid}


Dalam hal pembelajaran bahasa Arab, pesantren modern sudah menggunakan metode yang bervariasi dengan mengikuti perkembangan kemajuan zaman dan teknologi, juga dengan inovasi-inovasi pembelajaran yang lain. Sementara itu, pesantren tradisional masih menggunakan metode yang sejak dulu dipakai oleh pesantren-pesantren yaitu metode qawaid wa tarjamah atau yang dikenal juga dengan metode sorogan dan bandongan. Sorogan merupakan metode pembelajaran yang diterapkan pesantren hingga kini, terutama di pesantren-pesantren salaf. Usia dari metode ini diperkirakan lebih tua dari pesantren itu sendiri. Karena metode ini telah dikenal semenjak pendidikan Islam dilangsungkan di langgar, saat anak-anak belajar Alquran kepada seorang ustaz atau kiai di kampung-kampung. Pada masa lalu, di langgar-langgar atau surau seorang kiai akan membacakan ayat Alquran terlebih dahulu, kemudian muridnya mengikuti dan menirukannya secara berulang kali. Namun, lama-kelamaan metode ini dipraktikkan di dalam pesantren, yang merupakan satu-satunya lembaga pendidikan Islam terbesar di Indonesia. Dengan menggunakan metode sorogan, setiap santri akan mendapat kesempatan untuk belajar secara langsung dengan ustad atau kiai tertentu yang ahli dalam mengkaji kitab kuning, khususnya santri baru dan santri yang benar-benar ingin mendalami kitab klasik. Dengan metode ini, kiai tersebut dapat membimbing, mengawasi, dan menilai kemampuan santri secara langsung. Metode Ini sangat efektif untuk mendorong peningkatan kualitas santri tersebut. Dengan menggunakan metode sorogan, santri diwajibkan menguasai cara pembacaan dan terjemahan secara tepat dan hanya boleh menerima tambahan pelajaran bila telah berulang-ulang mendalami pelajaran sebelumnya. Hal ini tentunya menuntut kesabaran, kerajinan, ketaatan, dan disiplin pribadi santri.

Metode ini pernah diilustrasikan oleh Abu Bakar Aceh sebagaimana diukutip Ridwan Nasir dalam buku Mencari Tipologi Format Pendidikan Ideal: Pondok Pesantren di Tengah Arus Perubahan. Dalam mengadakan pengajian sorogan, guru atau kiai biasanya duduk di atas sepotong sajadah atau sepotong kulit kambing atau biri-biri, dengan sebuah atau dua buah bantal dan beberapa jilid kitab di sampingnya yang diperlukan. Sementara, 
murid-muridnya duduk mengelilinginya. Ada yang bersimpul, ada yang bertopang dagu, bahkan ada yang bertelungkup setengah berbaring, sesuka-sukanya mendengar sambil melihat lembaran kitab yang dibacakan gurunya.

Tak kalah menariknya, di pesantren juga kerap menggunakan metode bandongan atau bandungan. Istilah bandungan berasal dari bahasa Sunda ngabandungan yang berarti memperhatikan secara saksama atau menyimak. Dengan metode ini, para santri akan belajar dengan menyimak secara kolektif. Namun, dalam bahasa Jawa, bandongan disebutkan juga berasal dari kata bandong, yang artinya pergi berbondong-bondong. Hal ini karena bandongan dilangsungkan dengan peserta dalam jumlah yang relatif besar.

Penulis buku Tradisi Pesantren Zamakhsyari Dhofier mengatakan, dalam menggunakan sistem ini, sekelompok murid yang terdiri antara 5 sampai 500 orang mendengarkan seorang guru yang membaca, menerjemahkan, menerangkan, dan sering kali mengulas buku-buku Islam dalam bahasa Arab. Setiap murid memperhatikan bukunya sendiri dan membuat catatan-catatan (baik arti maupun keterangan) tentang kata-kata atau buah pikiran yang sulit. Metode kedua ini oleh beberapa kalangan disebut juga wetonan, yang berasal dari kata wektu yang berarti waktu. Hal ini karena pengajian-pengajian tersebut hanya diberikan pada waktuwaktu tertentu, yaitu sebelum atau sesudah melakukan shalat fardhu di masjid atau mushala pesantren. Dalam mempraktikkan metode ini, seorang kiai akan membacakan kitab kuning dan menerjemahkannya ke dalam bahasa ibu, seperti ke bahasa Madura, Sunda, atau Jawa. Kemudian, santri menuliskan terjemahan kata demi kata seperti yang disampaikan oleh kiai tersebut. Sistem penerjemahan disampaikan sedemikian rupa sehingga para santri mudah mengetahui baik arti maupun fungsi kata dalam suatu rangkaian kalimat dalam kitab kuning tersebut. Metode bandongan adalah metode transfer keilmuan atau proses belajar mengajar yang ada di pesantren yang mengajarkan khusus pada kitab kuning. Kiai tersebut membacakan, menerjemah, dan menerangkannya. Sedangkan, santri atau murid mendengarkan, menyimak, dan 
mencatat apa yang disampaikan oleh kiai yang memberi pengajian tersebut. Bandongan merupakan metode utama sistem pengajaran di lingkungan pesantren. Kebanyakan pesantren, terutama pesantren-pesantren besar, menyelenggarakan bermacam-macam kelas bandongan atau halaqah untuk mengajarkan kitab-kitab, mulai dari kitab dasar sampai kitab-kitab yang bermuatan tinggi. Pada intiya, metode sorogan dan bandongan sama-sama memiliki ciri pemahaman yang sangat kuat dalam pengajaran ilmu agama. Namun, kedua metode tersebut dianggap tidak cukup efektif untuk mengembangkan nalar kritis santri karena sedikitnya kesempatan yang diberikan untuk mempertanyakan kebenaran materi yang dipelajarinya. Metode ini sangat minim terjadinya proses dialog lantaran sedikitnya waktu pengajian yang diberikan. ${ }^{11}$

Dalam konteks pendidikan di pesantren, menurut Nurcholish Madjid, istilah kurikulum tidak dikenal di dunia pesantren, terutama masa prakemerdekaan, walaupun sebenarnya materi pendidikan sudah ada dan keterampilan itu ada dan diajarkan di pesantren. Kebanyakan pesantren tidak merumuskan dasar dan tujuan pesantren secara eksplisit dalam bentuk kurikulum. Tujuan pendidikan pesantren ditentukan oleh kebijakan Kiai, sesuai dengan perkembangan pesantren tersebut termasuk di dalamnya adalah pembelajaran bahasa Arab. Pada pondok pesantren tradisional, pembelajaran bahasa ini lebih diutamakan pada penguasaan tata bahasa. Tata bahasa ini dipelajari dalam dua pembahasan utama yang dikenal dengan ilmu nahwu dan sharaf. Kedua ilmu ini merupakan hal urgen yang harus dikuasai untuk bisa mengetahui struktur dari bahasa yang menjadi bahasa persatuan umat Islam ini. Dalam Bahasa Inggris, nahwu dan sharaf biasa disebut dengan grammar atau structure, yaitu yang membahas seputar bentuk dan perubahan kata serta penggunaannya dalam suatu kalimat. Di pesantren tradisional, pembelajarann nahwusharaf ini bertingkat dengan berpedoman kitab salaf atau klasik

${ }^{11}$ http://www.republika.co.id/berita/koran/dialog-jumat/16/04/08/o5ar464-sorogandan-bandongan-metode-khas-pesantren, diunduh pada 1 Nopember 2017. 
dalam ilmu nahwu sharaf. Semisal kitab Jurumiyah, 'Imrithi, Alfiyah, Amtsilatut Tashrifiyah, Maqsud, dan sebagainya. ${ }^{12}$

Pesantren tradisional/salaf merupakan benih awal bagi berkembangnya pesantren di Indonesia. Hal ini dikarenakan pesantren salaf merupakan manifestasi dunia pesantren yang berusaha untuk tetap berada dalam rel tujuan awal pendirianya, yakni sebagai lembaga syi'ar (dakwah) dan pendidikan agama Islam. Sebagai sebuah lembaga pendidikan Islam, pesantren salaf di awal perkembangannya hanya mengajarkan agama dengan sumber mata pelajaran berupa kitab-kitab berbahasa Arab yang masuk dalam kategori mu'tabarah. Pelajaran yang biasanya dikaji meliputi: Al Qur'an dengan tajwid dan tafsirnya; hadits dengan musthalahnya, bahasa Arab dengan nahwu, sharf, balaghah, arudl, dan mantiqnya; fiqih dengan hukum-hukum dan ushul fiqihnya; serta akhlaq dengan warna tasawufnya. Kitab-kitab yang dipakai, pada umumnya juga terbatas pad hasil karya ulama abad pertengahan (antra abad 12 - 15) yang kemudian lebih dikenal dengan istilah kitab kuning. Selain ilmu agama, bahasa Arab merupakan pelajaran pokok yang harus diikuti dan dikuasai oleh para santri. Sebab, tingkat penguasaan terhadap tata bahasa Arab seringkali dijadikan tolok ukur kualitas seorang santri untuk mendapatkan predikat Kiai. Maka, tidak heran jika kitab-kitab nahwu, (Jurumiyah, Mutamimah, Imrithi, serta Al fiyah), kitab-kitab sharah (al Amstilah at Tashrifiyah, Qawa'id al I'lal, Kaelani), serta kitab-kitab ilmu bahasa lainnya menjadi santapan keseharian di pesantren salaf. Selain sebagai standar kualitas determinasi tinggi dalam mempelajari ilmu bahasa (nahwu dan sharaf) di kaangan santri salaf juga disebabkan oleh berkembangnya jargon "As Sharfu Umm al Ulum wa al nahwu abuuhu" (sharaf adalah ibunya ilmu dan nahwu adalah bapaknya). Dalam tradisi salaf, penguasaan bahasa Arab tidak diikutinya kesungguhan dalam mempelajari ilmu tata bahasa Arab dengan usaha aplikatif untuk mempraktekkan bahasa Arab dalam kehidupan sehari-hari. Hal ini berakibat pada minimnya tingkat penguasaan santri terhadap mufradat bahasa Arab, sehingga tingkat keilmuan bahasanya adalah penguasaan

\footnotetext{
${ }^{12}$ Nurcholish Madjid, Bilik-Bilik Pesantren...h.59.
} 
bahasa pasif, bukan bahasa aktif. Maksudnya adalah bahwa pesantren salaf lebih mengutamakan penguasaan teks daripada penguasaan praktek.

Adapun menurut Ahmad Fuad Efendy, tujuan pembelajaran bahasa Arab di pesantren, sebagaimana metode yang digunakan yaitu metode qawaid wa tarjamah, maka pembelajaran tersebut mempunyai tujuan :

a. Menghafal kosa kata dan memahami arti bahasa sumber/asing lewat terjemahan, setelah terlebih dahulu menghafalkan kaidahkaidah bahasanya.

b. Peserta didik harus tahu pentingnya bahasa sumber/asing, membandingkannya dengan bahasa-bahasa lain, misalkan bahasa asal (bahasa ibu), dengan demikian maka pengajar akan lebih leluasa meluangkan waktunya mengajarkan tentang bahasa.

c. Memfokuskan pada keakuratan bahasa (Language Accuracy) dalam memahami kaidah-kaidah bahasa, ketika melakukan imla (dikte), menerjemahkan dan meminimalisir keahlian dalam berbahasa (Language Proficiency).

d. Mementingkan materi yang terdapat dalam buku ajar dan menelaah kaidah-kaidah yang terdapat di dalamnya, teks-teks, dan latihan-latihan.

e. Mementingkan aspek bacaan dan aspek bacaan tersebut diambil dari latihan menerjemahkan dari bahasa asal/ibu ke bahasa sumber/asing dan juga sebaliknya.

f. Banyak latihan menerjemahkan kalimat-kalimat dari bahasa asal/ibu ke bahasa sumber/asing dan sebaliknya, serta merangkai kalimat-kalimat yang terputus-putus. ${ }^{13}$

Berdasarkan atas uraian tersebut di atas, dapat diambil kesimpulan bahwa pendidikan bahasa Arab di pesantren tradisional masih menggunakan metode yang sejak awal digunakan oleh pesantren, yaitu metode qawaid wa tarjamah. Penggunaan metode pembelajaran yang bersifat klasik tersebut dikarenakan oleh beberapa sebab, diantaranya adalah :

${ }^{13}$ Ahmad fuad Effendy, Metodologi Pengajaran Bahasa Arab(Malang: Misykat, 2005), hal. 32 . 
a. Alasan spiritual, yaitu dengan mempelajari bahasa Arab berarti mempelajari bahasa al-Quran, maka nilai spiritualnya sangat tinggi, walaupun dengan metode yang tetap dan tidak berkembang, namun akan tetap membawa dampak yang baik.

b. Pengkultusan, yaitu mengkultuskan seseorang dan juga mengkultuskan berkah dalam pemelajaran di pesantren. Di setiap pesantren yang dipimpin oleh seorang kiai, maka kiai tersebut akan sangat dipatuhi dan diikuti atau bahasa pesantrennya adalah takdzim dengan seorang kiai adalah suatu keharusan bagi seorang santri, dengan demikian segala sesuatu yang dilakukan oleh seorang kiai adalah benar adanya tanpa ada upaya untuk merubah atau berinovasi. Begitu juga dengan mengikuti pembelajaran di pesantren, jika mendapatkan ilmu yang berkah, bagaimanapun proses yang dilakukan maka akan mendapatkan hasil yang maksimal.

\section{E. Simpulan}

Pembelajaran bahasa Arab yang ada di pondok pesantren tradisional hingga saat ini sudah berjalan dengan baik, bahkan sudah teruji berabad-abad lamanya, yaitu dengan menghasilkan ulama-ulama yang mumpuni dalam ilmu agama dan bahasa Arab. Sehingga kemudian model pendiikan ala pesantren tersebut menjadi acuan pendidikan-pendidikan yang hingga saat ini dengan lebih mengembangkan model serta pola pembelajaranya. Hal ini memang tidak terlepas dari metode yang dilakukan serta kesungguhan dari para pembelajar atau santri di pesantren tersebut. Namun akan sangat baik sekali jika metode yang sudah ada tersebut didukung dan dikembangkan lagi dengan mengikuti kemajuan ilmu pengetahuan dan teknologi, sehingga pembelajaran yang memang sudah baik sebelumnya akan menjadi lebih baik lagi, serta akan mempermudah para santri dalam mempelajari bahasa Arab.

\section{DAFTAR PUSTAKA}

Abdul Aziz ibn Ibrahim al-'Ushaili, Tharâiq Tadrîs al-Lughah al-'Arabiyah lin Nâtiqîn bi Lughatin Ukhrâ(Riyadh: Jami'ah Imam Muhammad ibn Su'ud al-Islamiyah, $2002 \mathrm{M} / 1423 \mathrm{H}$ ) 
Abdul Hamid, Uril Baharuddin, Bisri Mustofa, Pembelajaran Bahasa Arab ( Malang : UIN Malang Press, 2008)

Ahmad fuad Effendy, Metodologi Pengajaran Bahasa Arab(Malang: Misykat, 2005)

Muhammad Jamhuri, Sejarah dan Perkembangan Pendidikan Islam di Indonesia,(Tangerang: Sekolah Tinggi Agama Islam AsySyukriyyah,1990)

Ahmad Izzan, Metodologi Pembelajaran Bahasa Arab, (Bandung : Humaniora, 2009)

Fatah, H Rohadi Abdul, Taufik, M Tata, Bisri, Abdul Mukti. Rekontruksi Pesantren Masa Depan, (Jakarta Utara: PT. Listafariska Putra, 2005)

Hamid Fahmi Zarkasyi, Pengembangan Institusional dan Kurikuler Pesantren Salafiyah, Makalah "Seminar Pengembangan Pesantren Salafiyah" yang diselenggrakan Puslitbang Pendidikan Agama dan Keagamaan, tanggal 8-10 Juni 2007.

http://www.inidalwa.ac.id/pembelajaran-bahasa-arab-di-pesantrentradisional-kurikulum-tujuan-bahan-ajar-dan-metode/

http://www.republika.co.id/berita/koran/dialogjumat/16/04/08/o5ar464-sorogan-dan-bandongan-metode-khaspesantren

Nurcholish Madjid, Bilik-Bilik Pesantren Sebuah Potret Perjalanan (Jakarta: Paramadina, 1997)

Yayan Nurbayan, Metodologi Pembelajaran Bahasa Arab, (Bandung : Zein Al Bayan, 2008) 